\title{
Implications of Experiences in the Family of Origin and Infidelity in Violence Loving Relationships
}

\author{
Patrícia Manozzo Colossi*, 1, 2 \\ Orcid.org/0000-0002-2038-1491 \\ Denise Falcke ${ }^{2}$ \\ Orcid.org/0000-0002-4653-1216 \\ ${ }^{1}$ Faculdades Integradas de Taquara, Taquara, RS, Brasil \\ ${ }^{2}$ Universidade do Vale do Rio dos Sinos, São Leopoldo, RS, Brasil
}

\begin{abstract}
The experiences of partners in their families of origin, the circumstances of everyday life and aspects of infidelity in the marital relationship have been studied to explain the genesis of intimate partner violence. This study investigated the experiences of the family of origin, which sociodemographic data and what factors associated with infidelity have a greater predictive power of intimate partner violence, besides the possible interactions between these variables. A quantitative, correlational and explanatory study was developed with 600 participants (384 men, 216 women), correlations were established and linear regression models were proposed. The results identified that circumstances of daily life (such as gender, having children or not, partner's age) and experiences in the family of origin (physical neglect, sexual abuse and parental alliance) contribute to the explanation of the different expressions of violence in the couple. Infidelity, although correlated with violence, did not prove to be a predictor. Physical neglect and sexual abuse were identified as predictors of physical violence while the dysfunctional parental alliance was a predictor of psychological violence. The women showed higher rates of psychological violence while men presented greater perpetration of sexual coercion. The marital clinic is a highlighting in this context, since it proposes to welcome and treat the conjugal relationship in its structuring and relational aspects, improving the establishment of more balanced, stable and functional relational models.
\end{abstract}

Keywords: Marital violence, infidelity, family of origin, regression analysis.

\section{Implicações das Experiências na Família de Origem e de Infidelidade na Violência dos Relacionamentos Amorosos}

\section{Resumo}

Experiências dos parceiros nas famílias de origem, circunstâncias da vida cotidiana e aspectos da infidelidade na relação conjugal têm sido estudados para explicar a gênese da violência no casal. Este estudo investigou as experiências da família de origem, quais variáveis sociodemográficas e que fatores associados à infidelidade possuem maior poder preditivo da violência nos relacionamentos íntimos,

* Mailing address: Av. Oscar Martins Rangel, 4500. Bairro Fogão Gaúcho, Taquara, RS, Brazil. 95612190 Phone: (51) 3541.6689 / +1 (407) 668.5262 Email: pmcolossi@gmail.com. 
além das suas possíveis interações. Um estudo quantitativo, correlacional-explicativo foi desenvolvido com 216 homens e 384 mulheres $(n=600)$. Correlações foram estabelecidas e modelos de regressão linear foram propostos. Resultados identificaram que circunstâncias da vida cotidiana (sexo, ter filhos ou não, idade dos parceiros) e experiências na família de origem (negligência física, abuso sexual e aliança parental) contribuem para a explicação das expressões de violência no casal. A infidelidade se correlacionou com a violência, mas não se mostrou preditora. Negligência física e abuso sexual identificaram-se como preditores da violência física e a aliança parental disfuncional mostrou-se preditora da violência psicológica. Mulheres revelaram maiores taxas de violência psicológica enquanto homens apresentaram maior perpetração da coerção sexual. Destaca-se a importância da clínica conjugal que se propõe a acolher e tratar a relação conjugal em sua estrutura relacional, favorecendo o estabelecimento de modelos mais equilibrados, estáveis e funcionais.

Palavras-chave: Violência conjugal, infidelidade, família de origem, análise de regressão

\section{Implicaciones de las Experiencias en la Familia de Origen y la Infidelidad en la Violencia de las Relaciones Românticas}

\section{Resumen}

Las experiencias de los cónyuges en sus familias de origen, y las circunstancias de la vida cotidiana, infidelidad en la relación conyugal se ha estudiado con el fin de explicar la génesis de la violencia en la pareja. Este estúdio investigó las experiências de la família de origen, que las variables sociodemográficas y fatores associados a la infidelidade tienen mayor poder predictivo de la violência na las relaciones íntimas, además de las posibles interaciones entre estas variables. Un estudio explicativo cuantitativo, correlacional se llevó a cabo con 384216 hombres y 216384 mujeres $(n=600)$. Las correlaciones se establecen y se propusieron modelos de regresión lineal. Resultados encontrado que las circunstancias de la vida cotidiana (sexo, tienen hijos o no, la edad de los socios) y experiencias en la familia de origen (abandono físico, el abuso sexual y la alianza de los padres) contribuir a una explicación de las expresiones de la violencia no se doble. El infidelidadese correlacionada con la violencia, pero no fue predictiva. abandono físico $y$ el abuso sexual fueron identificados como predictores de la violencia física у ииа alianza parental disfuncional demostrado ser un predictor de la violencia psicológica. Las mujeres mostraron tasas más altas de violencia psicológica, mientras que los hombres eran más comisión de coacción sexual. Se destaca la importancia de la clínica civil que ofrece un acogedor y es una relación marital en una estructura relacional, favoreciendo la creación de modelos más equilibradas, estables y funcionales.

Palabras clave: La violencia de pareja, infidelidad, familia de origen.

Intimate partner violence has long been a subject of interest in the literature and has been studied from different perspectives and contexts (Colossi \& Falcke, 2013; Oliveira, Gessner, Brancaglioni, Fonseca, \& Egry, 2016; World Health Organization [WHO], 2016). Its most frequent manifestations are conceptually divided into physical, sexual and psychological violence, and occur either alone, or in combination with one another (Hirigoyen, 2006). In Brazil, the law which deals specifically with violence against women also makes reference to property and moral violence (Law no. 11.340, 2006 [Maria da Penha]).

Global data suggests that over $38 \%$ of female homicides are committed by their intimate partners (WHO, 2016). In Spain, a study of 1076 female victims of violence revealed that $27.6 \%$ of participants had suffered some form of aggression, which $42.7 \%$ of them attributed to their partners (Martín-Baena, Montero-Piñar, Escribà-Agüir, \& Vives-Cases, 2015). In Brazil, this phenomenon is also highly prevalent: according to recent estimates, one in 
every three women has been the victim of some sort of violence in their lifetime, and $40 \%$ to $70 \%$ of homicides against women are committed by intimate partners (Rosa, Boing, Büchele, Oliveira, \& Coelho 2008).

Epidemiological studies have estimated that $30 \%$ to $50 \%$ of women experience some form of intimate partner violence (Lamoglia \& Minayo, 2009; Rodrigues, Gomes-Sponholz, Stefanelo, Nakano, \& Monteiro, 2014; Vieira, Perdona, \& Santos, 2011). A study of different types of violence in the Brazilian state of Pernambuco reported a prevalence of $52.7 \%$ for emotional violence, $46.1 \%$ for physical violence and $13.6 \%$ for sexual violence in a sample of 245 women aged 15 to 49 (Barros et al., 2016). An even higher figure was reported by Dourado and Noronha (2015) in a study conducted in Bahia, where $63.2 \%$ of women experienced intimate partner violence, revealing the endemic nature of this phenomenon. However, these studies were conducted from a gender perspective, where males are often the perpetrators deserving of punishment, and women are victims who need care and protection. Violence against men is also known to occur. As recently as the last decade, Hirigoyen (2006) found that 3\% to $5 \%$ of heterosexual males were victimized by their partners. Yet this phenomenon may be underreported, since men are less likely to inform the authorities of any violence they may have suffered at the hands of their partners, possibly out of shame, lack of social acceptance and/or fear of ridicule (Shuler, 2010). These findings were corroborated by Panuzio and DiLillo (2010), who found that $24 \%$ to $44 \%$ of women reported to engaging in some form of violence against their husbands in the early stages of marriage, with most couples reporting that the violence was bidirectional. A more recent study conducted in France involving 707 victims of intimate violence revealed that $13 \%$ of men had been victimized by their partners (Le BlancLouvry, Thureau, Gricourt, \& Proust, 2015). A study by Chang et al. (2011) in the United States of America reported lifetime prevalence rates of $63 \%$ for intimate partner violence against women and $32 \%$ for intimate partner violence against men, which highlights the fact that this type of violence is often bidirectional.

The complexity of intimate partner violence reflects its multifaceted nature and multifactorial etiology. Attempts to explain the origins of this phenomenon have led to the identification of several possible causes. Flynn and Graham (2010) proposed a conceptual model comprised of three levels of factors which may contribute to marital violence: (1) Background and personal characteristics of perpetrators and victims; (2) Current life circumstances; (3) Immediate precursors or precipitators. The analysis of 16 empirical studies on the topic led authors to conclude that in most cases, the violence was attributed to level three factors, which refer specifically to immediate causes. These may include jealousy, infidelity and psychoactive substance abuse. Infidelity is an immediate precipitator of intimate partner violence (Flynn \& Graham, 2010), and a growing phenomenon in both genders, as reflected by the clinical experience of couples therapists (Prado, 2012).

These findings speak to the importance of an in-depth study of these topics in order to identify the associations between them. These include both current and previous life experiences which may be associated with intimate partner violence.

\section{Experiences in the Family of Origin and Intimate Partner Violence}

Studies have identified an association between individuals' experiences in their families of origin and the occurrence of intimate partner violence, which underscores the role of the family in establishing behavior patterns which are learned and maintained across generations (Marasca, Colossi, \& Falcke, 2013; Paradis et al., 2009; Pedro, 2013). Prior experiences of family violence, either as a victim or as a witness, are predictive of violent marital relationships in adulthood (Colossi, Marasca, \& Falcke, 2015; Milner et al., 2010), possibly because this leads individuals to naturalize violence and see the relational patterns they have learned as children as a model to be followed (Godbout, Lussier, \& Sabourin, 2006; Marasca et al., 2013). 
According to the concept of intergenerationality, the influence of childhood experiences on subsequent development may be attributed to the reliance on caretakers and relationships as models to be reproduced in life (Black, Sussman, \& Unger, 2010; Gover, Park, Tomsich, \& Jennings, 2011; Kerley, Xu, Sirisunyaluck, \& Alley, 2010; Pedro, 2013). Children and adolescents exposed to violent environments may therefore learn that violence is a part of relationships, so that they naturalize it and use it as a model for intimate relationships in adulthood, perpetuating the cycle of violence. In the present study, intergenerationality will be defined as the set of family experiences which are transmitted from one generation to the next (Wagner, 2014). It is not merely an intrapsychic phenomenon (Almeida, 2008), and can influence the perpetuation of family interaction patterns over time, even when those involved are not explicitly aware of engaging in this behavior (Falcke, \& Wagner, 2005).

Studies of the relationship between the family of origin and intimate partner violence have found the latter to be associated with experiences such as physical and/or sexual abuse (Fergusson, 2011; Yoshihma \& Horrocks, 2010); neglect (Fang \& Corso, 2007); parental substance abuse (Alexander 2011; Whiting, Simmons, Havens, Smith, \& Oka, 2009); caretaker psychological distress (Godbout et al., 2006; Whiting et al., 2009) and parental decision-making styles (Alexander 2011). The aforementioned studies sought to investigate which aspects of the family of origin may be associated with conjugal violence in adulthood. All authors identified positive associations between abuse in the family of origin and conjugal violence in adulthood, though the relatively low predictive value of one factor over the other underscores the need for more in-depth studies of this phenomenon, in order to identify additional variables which may contribute to the repetition of learned violent behaviors or, conversely, allow for the cycle to be broken. In a systematic review about intimate partner violence and experiences in the family of origin, Marasca et al. (2013) noted the scarcity of international research on the topic; a similar pattern emerges in the national literature, which accounted for only $3.17 \%$ of worldwide publications on the topic between 2006 and 2011, underscoring the need for further research in this area of study.

\section{Current Life Circumstances and Intimate Violence}

Studies of the association between couples' current circumstances and the occurrence of marital violence have found the latter to be related to sociodemographic variables including gender, presence and number of children, as well as partner age (Colossi, Razera, Haack, \& Falcke, 2015; Kronbauer \& Meneghel, 2005). Yet the study of gender differences in the context of partner violence has not produced consistent results. Though many studies find that the majority of perpetrators of intimate partner violence are male (Kim, Laurent, Capaldi, \& Feingold, 2008; Martínez \& Marín, 2009; Trindade, Almeida, \& Rozendo, 2008; Vatnar \& Bjorkly, 2009), others identify significant gender differences in the type of violence committed, where males are more likely to resort to physical and sexual violence, while women tend to engage in verbal and psychological aggression (Carvalho, Destro, Faust, Coelho, \& Boing, 2010; Colossi, Razera, et al., 2015; D'Oliveira et al., 2009). Therefore, although both men and women can be victims or perpetrators, gender still plays a major role in the study of intimate partner violence (D'Oliveira et al., 2009).

On the other hand, some studies have identified no significant differences in perpetration rates between men and women (Colossi, Razera, et al., 2015; Follingstad \& Edmundson, 2010; Lamoglia \& Minayo, 2009). Though these investigations vary in their focus, they agree that couples may reciprocally engage in different forms of aggression (Colossi \& Falcke, 2013; Lamoglia \& Minayo, 2009), especially when psychological violence is involved (Colossi \& Falcke, 2013; Follingstad \& Edmundson, 2010).

Having children is one of the life circumstances which has been found to be associated with the occurrence of intimate partner violence. 
Studies have found that the number of children is positively associated with the likelihood of sexual coercion in the relationship (Colossi, Razera, et al., 2015; Kronbauer \& Meneghel, 2005). Similarly, studies find that formal marriage, as opposed to other types of relationship, is a protective factor against intimate violence (D’Oliveira et al., 2009; Vieira et al., 2011). These investigations find that, in the context of marriage, the violence is often resolved by separation or divorce. As such, since intimate violence in married couples usually leads to separation, the prevalence of this phenomenon in formal unions is relatively low. This may be why marriage is associated with a lower prevalence of intimate partner violence. On the other hand, couples in shorter or more casual relationships are at greater risk of establishing new violent partnerships, leading to an increased frequency of violent behaviors in relationships other than formal marriage.

Studies of partner age find this variable to be inversely associated with physical and psychological intimate violence (Colossi, Razera, et al., 2015; D’Oliveira et al., 2009). It is possible that emotional maturity facilitates engagement in reflection or deliberation during conflict situations (Colossi, Razera, et al., 2015). A similar observation was made by D'Oliveira et al. (2009) who found that tolerant and thoughtful responses to conflict were more common in older couples. On the other hand, a study by Kronbauer and Meneghel (2005) found that age was positively associated with intimate partner violence.

The couple's life circumstances are also known to play a role in the occurrence of intimate partner violence. These factors must continue to be investigated in order to comprehend how they contribute to the onset of partner violence in different situations.

\section{Infidelity and Intimate Partner Violence}

In contemporary couples therapy, infidelity may be understood as a symptom of pathology in the relationship, but also as a feature of the conjugal dynamics of a given couple (Prado, 2012). Regardless of how it takes place, it can have major repercussions, resulting in both suffering and possible psychopathology (Baucom, Snyder, \& Dixon, 2008; Prado, 2012; Whisman \& Baucom, 2012).

Studies have found that episodes of infidelity may compromise the relationship, leading to excessive control, pathological jealousy, accusations and humiliation even in the absence of real danger, resulting in psychological violence which reinforces dysfunctional patterns in the relationship (Conroy, 2014; Ortiz, Leiva, \& Jacinto, 2009; Wilson, Mattingly, Clark, Weidler, \& Bequette, 2011). Partners facing infidelity may also have difficulty managing their emotions, and resort to psychological aggression as a form of punishment, amplifying the conflict and contributing to impairments in the mental health of both partners. Therefore, infidelity - be it real or suspected - can contribute to the onset of intimate violence in all its forms (Ortiz et al., 2009).

Though the coexistence of infidelity and violence in marital relationships has not been extensively studied, it is known to result in considerable weakening of relational bonds (Brito \& Cavalcanti, 2014; Colossi \& Falcke, 2013; Conroy, 2014). Both topics are therefore commonly discussed in the context of psychotherapy, since they inflict suffering both on members of the couple but also on all other members of the family (Colossi, Razera, et al., 2015), who may repeat the patterns experienced in the family of origin in future relationships (Hetzel-Riggin \& Meads, 2011; Paradis et al., 2009).

If infidelity is understood as a dysfunctional aspect of intimate relationships, then violence can be defined a dysfunctional pattern of conflict resolution. Violent relational dynamics cannot be reduced to a unidirectional phenomenon, with perpetrators and victims forming an asymmetrical pattern of dysfunction, where one individual has all the power over the other. Rather, it should be seen as an interactional model reinforced by the couple itself, where communication is incongruent, and the aforementioned features 
emerge as possibilities of engaging with the other (Peixoto \& Heilborn, 2016).

The analysis of a possible association between partner violence and infidelity may lead to the identification of predictors of marital violence, deepening the comprehension of violent marital dynamics. Violence may be expressed as a conflict resolution strategy in situations of infidelity (Flynn \& Graham, 2010; Paixão et al., 2014; Quissini \& Coelho, 2014; Wilson et al., 2011), which is why these phenomena sometimes co-occur.

These findings identify infidelity, experiences in the family of origin and circumstances of daily life as independent variables which may explain the occurrence of marital violence. Although these associations have already been proven, little is known about the interaction between specific experiences in the family of origin, the sociodemographic aspects associated with infidelity and the occurrence of intimate partner violence. In light of these observations, the aim of the present study was to investigate which experiences in the family of origin, sociodemographic variables and factors associated with infidelity would be the strongest predictors of intimate partner violence, while also looking at the interaction between these variables. Rather than adopting a linear approach to presenting our findings, this study was conducted from a systemic perspective, with a focus on contemplating and integrating the different aspects of violence in order to discuss our results.

\section{Method}

\section{Study Design}

This was a quantitative study, with a correlational and explanatory design.

\section{Participants}

The sample consisted of 216 men and 384 women $(n=600)$ recruited through social media. Participants were at least 18 years of age, and had been in a heterosexual relationship (dating, common law or married) for at least six months. The sample was selected by convenience, where the first participants were recruited from the researchers' social networks and asked to refer other individuals who may wish to take part in the study, as per the "snowball" method.

The sample characteristics are shown in Table 1:

Table 1

Sample Characteristics

\begin{tabular}{lccc}
\hline & & Frequency & Percentage (\%) \\
\hline Gender & Female & 384 & 64.0 \\
Children & Male & 216 & 36.0 \\
& Yes & 184 & 30.8 \\
Relationship type & No & 414 & 69.2 \\
& Dating & 215 & 35.8 \\
& Cohabiting/common-law & 179 & 29.8 \\
Education & Married & 206 & 34.4 \\
& No formal education & 1 & 0.2 \\
& Primary education & 12 & 2.0 \\
& Secondary education & 219 & 37.0 \\
Currently employed & University degree & 202 & 34.1 \\
& Graduate degree & 158 & 26.7 \\
& Yes & 482 & 80.9 \\
& No & 114 & 19.1 \\
\hline
\end{tabular}




\section{Instruments}

Sociodemographic Questionnaire. A specially designed self-administered questionnaire was used to collect information on sociodemographic characteristics. This instrument contained 13 questions about gender, age, romantic partnership status, children, education and current employment.

Family Background Questionnaire (FBQ). This is a self-administered instrument with 179 questions to be answered on a fivepoint Likert scale. The questions comprise 22 subscales which refer to different aspects of respondents' recollected experiences in their family of origin. In the present study, the following FBQ subscales were used: physical neglect, maternal and paternal physical abuse, sexual abuse, maternal and paternal substance abuse, maternal and paternal psychological adjustment, and parental coalition (Melchert, 1998). The Cronbach's alpha of the subscales ranged from 0.737 to 0.894 , while the instrument as a whole had an alpha value of 0.909, demonstrating excellent reliability.

\section{Revised Conflict Tactics Scale (CTS}

2). This instrument was developed by Straus, Hamby, Boney-McCoy, and Sugarman, (1996) and adapted to Portuguese by Moraes, Hasselmann, and Reichenheim (2002). The aim of the CTS2 is to evaluate intimate partner violence. It contains 78 closed questions, and evaluates the extent to which the respondent and their partner engage in negotiation, psychological aggression, physical violence, assault and sexual coercion. The present study used the CTS2 subscales pertaining to physical, psychological and sexual violence.

Perceptions of Dating Infidelity Scale (PDIS). The PDIS was developed in North America by Wilson et al. (2011) and adapted to Portuguese through a rigorous translation process. The instrument was independently translated by four professionals who worked in the area of interest, two of whom were involved in the adaptation study, while the other two were not. The four translations were compared and synthesized into a single version, resolving any semantic ambiguities and giving rise to a fifth version of the scale, kept as similar as possible to the original instrument. This version was back-translated to English by a bilingual professional, in order to confirm the accuracy of the translated words and expressions. The individual responsible for the back-translation then compared his work to the original scale to resolve any linguistic ambiguities. The accuracy of the translation was confirmed by a pilot study which produced similar findings to those obtained with the original scale. It is a checklist which evaluates the extent to which the respondent approves of a series of infidelityrelated behaviors. The present study used participants' total scores on the scale, which has a Cronbach's alpha value of 0.846 .

Attitudes Toward Infidelity Scale (ATIS). This is a North-American instrument developed by Whatley (2008), which requires that the respondent indicate the extent to which they agree with 12 infidelity-related behaviors. It was also submitted to a rigorous translation process into Brazilian Portuguese and yielded a Cronbach's alpha coefficient of 0.796 .

Tendency to Infidelity Scale (TIS). This instrument was developed and validated in North America by Drigotas, Safstrom, and Gentilia (1999). It evaluates the likelihood of an individual committing infidelity. It has also undergone a rigorous translation process into Portuguese. The scale contains 11 items answered on a Likert scale which evaluates the intensity of the emotional, physical and cognitive intimacy between the respondent and individuals outside their main relationship. In the present study, it had an alpha coefficient of 0.917 , reflecting an excellent ability to measure the intended construct. Given the complexity of the phenomenon of infidelity and the difficulties in its measurement, the present study evaluated the construct in three dimensions: perceptions of infidelity, attitudes toward infidelity and tendency to infidelity.

\section{Data Collection Procedures}

Data were collected by advertising the study on social networks and other electronic media, in order to publicize the study and inclusion criteria. 
Individuals who were interested in participating and met the aforementioned criteria were provided with a link to an online data collection platform. Participants were asked to share the link to the study with anyone they felt may also meet inclusion criteria for participation.

\section{Data Analysis Procedures}

Quantitative analyses were conducted using the Statistical Package for the Social Sciences (SPSS), version 22. Data were analyzed through descriptive, correlational and inferential statistics. Violent behaviors, infidelity and experiences in the family of origin were compared between groups (men/women; children/no children) using independent samples t-tests. The predictive power of infidelity and violence in the family of origin on intimate partner violence was investigated using stepwise regression analysis.

\section{Ethical Concerns}

After approval by the university ethics committee (Project number 13/182), the link to the study was posted and shared on social networks. This study was conducted according to the ethical guidelines for human research outlined in Resolution 510/2016 of the National Health Council. When participants accessed the data collection platform, they were initially presented with an informed consent form containing a description of the study as well as other relevant information they may wish to know before agreeing to participate. The data collection was only initiated after participants agreed to the conditions presented. Since the topics investigated in the present study may be considered taboo, digital data collection was preferred in order to allow participants to respond to the questionnaires in the safest and most appropriate times and locations possible.

Participants received information about the contents of the study, the anonymity of data collection, the fact that IP addresses were not tracked in this investigation, the safety of data storage, and the possibility of withdrawing from the study at any time. They were also informed that they would be contacted by the researchers if a need for psychological assessment or treatment was identified at some point in the study. Participants were also free to contact the researchers for referrals to the psychology clinic of the university where the study was conducted (where treatment is provided at no cost), or to a health service in their own community.

\section{Results}

The prevalence of different types of violence in the sample was $29.9 \%$ for sexual coercion, $31 \%$ for physical violence and $86.7 \%$ for psychological aggression. An independent samples T-test was used to compare violent behaviors between genders. A significant difference in the incidence of psychological aggression $(t=3.979 ; p<.01)$ was identified, with females $(m=7.59)$ engaging in this type of violence more often than their male counterparts $(m=5.50)$. The prevalence rates for sexual coercion also differed between genders ( $t=-$ $5.078 ; p<.01)$, as evidenced by the higher scores of men $(m=1.98)$ relative to women $(m=0.76)$ on this scale. No significant differences were observed in the prevalence of physical violence $(t=1.830 ; p>.05)$.

The same statistical test was used to investigate differences in the types of intimate partner violence between couples with and without children. The results revealed a significant difference in the frequency of psychological aggression $(t=3.465 ; p<.001)$ between these participant groups, where a higher frequency of this behavior was reported by couples with children $(m=0.9314)$. Rates of sexual coercion and physical violence did not significantly differ between couples with $(p>$ $.05)$ and without children $(p>.05)$.

Differences between the different types of relationship were evaluated using ANOVA. A significant difference in the frequency of psychological violence was observed depending on the type of relationship $(F=4.137 ; p<.05)$. 
The comparison between dating $(m=0.82)$ and cohabiting/common-law couples $\quad(m=0.92)$ showed that the latter had a significantly higher frequency of psychological violence than the former $(p<.05)$. The remaining values did not differ between groups $(p>.05)$.

A comparison of mean violence scores across education levels was also performed using ANOVA. Results revealed significant group differences in the frequency of psychological aggression $(t=2.296, p<.05)$ and sexual coercion $(t=4.182, p=.001)$, which were both more frequent in individuals with no formal education or primary school only. Age was not significantly associated with psychological $(p>.05)$ or physical $(p>.05)$ violence, though it was weakly correlated with sexual coercion $(r=-0.123, p<$ $.05)$, suggesting that older individuals were less likely to engage in this type of violence.

Results regarding infidelity revealed that $45 \% \quad(n=270)$ of the sample currently or previously engaged in some form of this behavior, while $55 \%$ of participants $(n=300)$ reported to having been faithful in every previous relationship. The difference in selfreported infidelity between males and females was evaluated using Chi-square tests, which revealed a significant difference between genders $\left(x^{2}=0.016 ; d f=3 ; p<.05\right)$, where males $(51.9 \%)$ had a higher frequency of extradyadic involvement than females (41.1\%). A similar statistical procedure was used to evaluate gender differences in the prevalence of perceived partner infidelity. However, these scores did not differ between groups $\left(x^{2}=3.043 ; d f=1 ; p>.05\right)$.

The occurrence of different forms of infidelity was compared between males and females using $t$-tests. Men obtained higher scores $(m=29.84)$ than women $(m=25.64)$ in the ATIS $(t=-3.681 ; p<.001)$. Similarly, the tendency to infidelity was significantly higher $(t=-3.758$; $p<.001)$ in males $(m=39.26)$ than females $(m=32.65)$. However, women obtained higher scores than men in a measure of perceptions of infidelity $(t=4.104 ; p<.001)$, where women exhibited more moral behavior $(m=40.31)$ than the men in the sample $(m=35.71)$.
The association between type of relationship and prevalence of different dimensions of infidelity was evaluated using ANOVA. No significant differences were identified in terms of perceptions $(F=1.118 ; p>.05)$ and tendency to infidelity between the participant groups $(F=1.223 ; \mathrm{p}>.05)$. However, attitudes toward infidelity did differ between relationship types $(F=5.050 ; p<.05)$. The comparison between dating $(m=25.01)$ and cohabiting/common-law couples $(m=28.76)$ showed that infidelity was significantly less common in the former relative to the latter $(p<.05)$.

Associations between experiences in the family of origin, dimensions of infidelity and intimate partner violence are shown in Table 2.

A history of physical neglect was associated with all three types of violence in both males and females. A similar finding was obtained with regards to the tendency to infidelity. The data also showed that the association between experiences in the family of origin, infidelity and intimate partner violence were stronger in females than males. Regression analysis was then used to determine the predictive power of each dimension of infidelity, experience in the family of origin and current life circumstance on different expressions of intimate violence, as shown in Table 3.

The regression models show that although correlations were identified between dimensions of infidelity and different types of violence, the former did not predict the latter in the present study. However, experiences in the family of origin had a clear impact on intimate partner violence, since parental coalition, sexual abuse and physical neglect were all significant predictors of both physical and psychological violence.

Gender was also a predictor of different types of violence. Current life circumstances as represented by sociodemographic variables such as gender, age, presence and number of children were significant predictors of psychological violence. Sociodemographic variables were also significant contributors to sexual coercion, as evidenced by the predictive power of gender and education in the regression analysis. 
Table 2

Correlation between Experiences in the Family of Origin and Intimate Partner Violence

\begin{tabular}{lcccccc}
\hline & \multicolumn{3}{c}{ Women } & \multicolumn{2}{c}{ Men } \\
\cline { 2 - 7 } & $\begin{array}{c}\text { Psychological } \\
\text { violence }\end{array}$ & $\begin{array}{c}\text { Sexual } \\
\text { coercion }\end{array}$ & $\begin{array}{c}\text { Physical } \\
\text { violence }\end{array}$ & $\begin{array}{c}\text { Psychological } \\
\text { violence }\end{array}$ & $\begin{array}{c}\text { Sexual } \\
\text { coercion }\end{array}$ & $\begin{array}{c}\text { Physical } \\
\text { violence }\end{array}$ \\
\hline Paternal Physical Abuse & $.156^{* *}$ & .082 & .045 & $.139^{*}$ & .084 & .136 \\
Maternal Physical Abuse & $.230^{* *}$ & .055 & $.173^{* *}$ & $.143^{*}$ & .070 & .082 \\
Sexual Abuse & $.155^{* *}$ & $.232^{* *}$ & $.138^{*}$ & .052 & -.057 & -.073 \\
Physical Neglect & $.196^{* *}$ & $.153^{* *}$ & $.189 * *$ & $.193^{* *}$ & $.197 * *$ & $.147^{*}$ \\
Paternal Substance Abuse & $.238^{* *}$ & $.215^{* *}$ & .088 & -.149 & .112 & -.104 \\
Maternal Substance Abuse & .070 & .040 & .047 & .022 & -.066 & .007 \\
Paternal Psych. Adj. & $-.183^{* *}$ & $-.116^{*}$ & $-.156^{* *}$ & $-.273^{* *}$ & -.093 & $-.186^{*}$ \\
Maternal Psych. Adj. & $-.250^{* *}$ & $-.113^{*}$ & $-.226^{* *}$ & $-.174^{*}$ & -.089 & -.085 \\
Parental Coalition & $-.262^{* *}$ & $-.157^{* *}$ & $-.242^{* *}$ & $-.292^{* *}$ & -.114 & -.090 \\
Infidelity-Attitudes & .092 & .023 & .095 & .113 & .029 & .133 \\
Infidelity-Perceptions & $.120^{*}$ & .056 & $.131^{*}$ & .028 & -.040 & .015 \\
Infidelity-Tendency & $.199 * *$ & $.163^{* *}$ & $.180^{* *}$ & .115 & -.055 & $.156^{*}$ \\
\hline
\end{tabular}

$* p<.05 ; * * p<.01$.

\section{Discussion}

The present study corroborates previous findings regarding the higher prevalence of psychological aggression over other forms of intimate partner violence (Black et al., 2010; Colossi, Razera, et al., 2015). Comparisons of the frequency of different types of violence among men and women agree with previous studies which identify men as the most likely perpetrators of sexual coercion (Schraiber, D’Oliveira, \& França, 2008) and women as the most likely perpetrators of psychological violence (Carvalho et al., 2010). As such, despite the findings of previous investigations conducted from a relational perspective (Colossi \& Falcke, 2013; Falcke \& Wagner, 2011), gender continues to play an important role in psychological and sexual intimate partner violence. However, it must be noted that in the present study, women were more likely than men to commit both physical and psychological violence, disagreeing with previous research which identified men as the most common perpetrators of intimate violence, especially physical aggression (Rosa et al., 2008; Tichy, Becker, \& Sisco, 2009). The aforementioned studies were conducted from a gender perspective, which tends to characterize men as perpetrators and women as victims. The feminist perspective considers intimate partner violence as a form of gender violence, perpetrated against women (Barros et al., 2016; Dourado \& Noronha, 2015; Vieira et al., 2011; WHO, 2016). The systemic approach adopted by the present study, on the other hand, sees violence as the product of a violent partnership and its relational features. Though these perspectives are distinct from one another and proposed different intervention strategies, they cannot be considered "dichotomous or concurrent perspectives, since systemic studies simply adopt a relational approach to a phenomenon that is already addressed in feminist studies" (Colossi \& Falcke, 2013, p. 311).

The present results also identified sociodemographic variables, such as age and the presence of children, which may contribute to the development of a violent marital relationship, a pattern already encountered in previous studies (Colossi et al., 2015; D’Oliveira et al., 2009). 
Table 3

Predictors of Intimate Partner Violence

\begin{tabular}{lccccr}
\hline Predictors of psychological violence & \multicolumn{2}{c}{ Unstandardized coefficients } & $\begin{array}{c}\text { Standardized } \\
\text { coefficients }\end{array}$ & \\
\hline \multicolumn{1}{c}{ Predictors } & $\mathrm{B}$ & Std. Error & Beta & $t$ & Sig. \\
\hline (Constant) & -2.130 & 14.329 & & -.149 & .882 \\
Parental Coalition & -.204 & .047 & -.262 & -4.296 & .000 \\
Gender & -2.028 & .847 & -.147 & -2.393 & .018 \\
Sexual Abuse & 1.687 & .640 & .161 & 2.638 & .009 \\
Children & -3.622 & 1.092 & -.254 & -3.318 & .001 \\
Age & -.129 & .057 & -.176 & -2.278 & .024 \\
\hline
\end{tabular}

$R=460^{\mathrm{e}} ; R^{2}=.212 ;$ adjusted $R^{2}=.194$

\begin{tabular}{|c|c|c|c|c|c|}
\hline \multirow{2}{*}{$\frac{\text { Predictors of sexual coercion }}{\text { Predictors }}$} & \multicolumn{2}{|c|}{ Unstandardized coefficients } & \multirow{2}{*}{$\begin{array}{r}\begin{array}{r}\text { Standardizec } \\
\text { coefficients }\end{array} \\
\text { Beta }\end{array}$} & \multirow[b]{2}{*}{$t$} & \multirow[b]{2}{*}{ Sig } \\
\hline & $\mathrm{B}$ & Std. Error & & & \\
\hline (Constant) & 2.176 & .918 & & 2.370 & .019 \\
\hline Gender & 1.158 & .347 & .213 & 3.335 & .001 \\
\hline Education & -.640 & .195 & -.209 & -3.285 & .001 \\
\hline
\end{tabular}

$R=.300 ; R^{2}=.090 ;$ adjusted $R^{2}=.082$

\begin{tabular}{lccccr}
\hline Predictors of physical violence & \multicolumn{2}{c}{ Unstandardized coefficients } & $\begin{array}{c}\text { Standardized } \\
\text { coefficients }\end{array}$ & \\
\hline \multicolumn{1}{c}{ Predictors } & $\mathrm{B}$ & Std. Error & Beta & $t$ & Sig. \\
\hline (Constant) & $-15,433$ & 6.316 & & -2.443 & .015 \\
Sexual Abuse & 1.162 & .284 & .255 & 4.095 & .000 \\
Physical Neglect & .183 & .042 & .269 & 4.320 & .000 \\
Gender & -.989 & .372 & -.164 & -2.657 & .008 \\
\hline
\end{tabular}

$R=.438 ; R^{2}=.192 ;$ adjusted $R^{2}=.181$

The present findings helped identify the life circumstances and demands which contribute to increasing stress levels, interfering with the maintenance of emotional equilibrium and selection of functional patterns of conflict resolution, as reported by Kline, Pleasant, Whitton, and Markman (2006) who found that marital conflict increases as couples become involved in daily problems.

The present findings also support previous observations regarding the relationship between partner violence and individual experiences in the family of origin (Colossi, Marasca, et al., 2015; Marasca et al., 2013; Milner et al., 2010). The experiences of each partner in their original family system make independent contributions to the onset of violence, and the experience of neglect, parental physical abuse, sexual abuse, and parental substance abuse in the family of origin are especially associated with future involvement in intimate partner violence (Fergusson, 2011; Godbout et al., 2006; Whiting et al., 2009). On the other hand, maternal and paternal psychological adjustment, as well as 
parental coalition, are protective factors against this form of violence. The fact that associations between dysfunctional family experiences and intimate partner violence were stronger in women than in men may reflect the greater involvement of daughters in mediating family relationships. This finding underscores the emotional burden of negative experiences in the family of origin, as they may be transferred to romantic relationships in adulthood, perpetuating a dysfunctional relational model (Marasca, et al., 2013; Santos, Marin, \& Castoldi, 2013).

Present findings regarding infidelity highlight possible differences between the moral behavior taught to men and women. Men were more likely to engage in extradyadic relations, and showed more favorable attitudes and a higher tendency toward infidelity than women, as has been reported in previous studies (Martins, 2012; Martins, Pereira, \& Canavarro, 2014). Differences between the attitudes of men and women toward infidelity may reflect a more general pattern of gender differences, since, socially, men have more permissive attitudes than women toward extradyadic involvement (Wilson et al., 2011). Similarly, female participants in the present study showed higher levels of moral judgment toward infidelityrelated behaviors, which may also be related to moral learning, as has been suggested in previous studies (Giordano, Manning, Longmore, \& Flanigan, 2012; Wilson et al., 2011).

Comparisons of the prevalence of different forms of infidelity across relationship types revealed a significant difference between dating and cohabiting/common-law couples $(p<.05)$. The former were less likely ( $m=25.01)$ to have been unfaithful than the latter $(m=28.76)$, which raises a series of questions about established relational models. It may be expected that partners in dating couples would be less committed to their relationship, given its relatively short duration. However, results showed that these individuals were actually more faithful than those who lived with their partners. It is therefore possible that partners in dating couples may feel less emotionally attached than those in longer relationships; dating couples may also be less exposed to daily conflicts involving children, for example. The duration of relationships must also be considered, since participants were required to have been in a relationship for at least six months prior to taking part in the study. A 6-month relationship is distinct from ten years' cohabitation, for instance, and may be less burdened by daily conflicts (Kline et al., 2006).

Previous studies have found infidelity to play a predictive role in intimate partner violence (Conroy, 2014; Ortiz et al., 2009; Wilson et al., 2011). However, in the present study, although correlations were identified between these variables, regression models did not find that the dimensions of infidelity explained a significant amount of the variance in intimate partner violence. The present study therefore demonstrated the relative strength of previous life experiences and circumstances over infidelity as contributors to violence, disagreeing with the findings of Flynn and Graham (2010), who found that immediate precipitators were the strongest predictors of different manifestations of intimate violence. This observation underscores the importance of considering a wide range of variables when evaluating intimate violence, highlighting the multifactorial etiology of the phenomenon and the contribution of different factors to the establishment of violent marital contexts in adulthood.

\section{Final Considerations}

Intimate partner violence is a multifactorial phenomenon, and a comprehensive approach is required to address the different aspects involved in these situations. The present study sought to identify aspects associated with the onset of intimate partner violence, including sociodemographic variables, the experiences of each individual in their family of origin, and factors related to infidelity, such as perceptions, attitudes and likelihood of extradyadic involvement. The results highlighted the connection between the experiences of the subject in their family of origin, their sociodemographic characteristics, and the different expressions of intimate violence. Current life circumstances 
were identified as important precipitators of violence, and it is possible that the negative or dysfunctional experiences of each partner in their family of origin may interfere with their ability to make use of healthy conflict resolution strategies.

Dysfunctional experiences in the family of origin may resurface in adulthood as a result of the repetition of relationship patterns learned in the past. Therefore, family-based interventions are crucial for promoting healthy family dynamics which can disrupt the cycle of violence, preventing the suffering of generation after generation. The cessation of violent behaviors such as neglect, different types of intrafamilial abuse and parental psychological maladjustment may be able to diminish, to some extent, the occurrence of violence in future partnerships. This would contribute to the psychological protection of children, who will have the opportunity to grow up in an environment that is more conducive to mental and relational health. This, in turn, may create a pattern of affective relationships that are more satisfactory and functional for the couples themselves, and more protective for any children born out of these relationships.

The present findings confirm those of the literature with regards to the variables studied, but also provide novel insight into these phenomena, since studies which have looked into the incidence of violence in intimate relationships often identify men as the main perpetrator. Yet the present findings revealed that women are the most common perpetrators of psychological violence, while men were usually responsible for incidents of sexual coercion. The absence of significant differences in the expression of physical violence between men and women highlights the interactional and recursive nature of intimate partner violence. Couples therapy may therefore play a crucial role in managing these situations, since its aim is precisely to care for and treat the structural and relational aspects of the marital relationship, promoting a more balanced, stable and functional relational model.

Though infidelity-related variables were not identified as causes of intimate partner violence in regression models, their correlations with this phenomenon warrant further investigation. The variables evaluated in the present investigation must undergo further study in order to comprehend how infidelity is associated with the onset of intimate partner violence. Though prior studies have found that the former predicts the latter, this was not the case in the present investigation. It is possible that when this variable is considered in combination with experiences in the family of origin and other characteristics of the individual or their current relationship, these factors may outweigh infidelity as predictors of intimate partner violence. However, intimate violence is a multivariate construct, and its association with infidelity must be considered, regardless of its strength. This is crucial for couples therapists responsible for the prevention and treatment of situations of marital conflict and emotional distress.

In order to extend and deepen the comprehension of the independent variables which may contribute to such an important marital context for couples and children born out of the relationship, future studies with similar goals to the present investigation must be carried out in different situations and samples. This may allow for the identification of new factors, allowing for the creation of interventions which may be more suited to the relational issues expressed in contexts of intimate partner violence. Since intimate violence is a multifaceted phenomenon, several factors may contribute to its onset in addition to those addressed in the present study, which may be an important limitation of the present study.

Nevertheless, this investigation hopes to contribute both to the advancement of theoretical knowledge, and to the development of intervention strategies. The present findings underscore the importance of counseling and treating couples with a focus on the constituent aspects of the marital relationship, regardless of the type of partnership (dating, commonlaw or marriage), rather than addressing each partner individually. The present findings may therefore shed light on the importance of addressing the marital dynamics and the way 
learned transgenerational patterns contribute to the development of the marital relationship in the context of couples therapy.

\section{References}

Alexander, P. C. (2011). Childhood maltreatment, intimate partner violence, work interference and women's employment. Journal of Family Violence, 26, 255-261. doi: 10.1007/s10896011-9361-9

Almeida, M. E. S. (2008). A força do legado transgeracional numa família. Psicologia: Teoria e Prática, 10(2), 215-230.

Barros, E. N., Silva, M. A., Gilliatt Hanois, F. N., Gomes Lucena, S., Ponzo, L., \& Pimentel, A. P. (2016). Prevalência e fatores associados à violência por parceiro íntimo em mulheres de uma comunidade em Recife/Pernambuco, Brasil. Revista Ciência \& Saúde Coletiva, 21(2), 591598. doi: 10.1590/1413-81232015212.10672015

Baucom, D. H., Snyder, D. K., \& Dixon, L. J. (2008). Couple therapy and the treatment of affairs. In A. S. Gurman, Clinical Handbook of Couple Therapy (4th ed.). New York: The Guilford Press.

Black, D. S., Sussman, S., \& Unger, J. B. (2010). A further look at the intergenerational transmission of violence: Witnessing interparental violence in emerging adulthood. Journal of Interpersonal Violence, 25(6), 1022-1042. https://dx.doi. org/10.1177/0886260509340539

Brito, R. S., \& Cavalcanti, P. P. (2014). Infidelidade masculina e violência sexual: Sentimentos das mulheres que as vivenciaram. Ciência et Praxis, 7(14), 13-18. Retrieved from http://www.scielo. $\mathrm{cl} /$ pdf/cienf/v14n2/art06.pdf

Carvalho, C., Destro, J. R., Faust, S. B., Coelho, E. B. S., \& Boing, A. F. (2010). Dinâmica da violência entre casais a partir da ótica da mulher agredida no Bairro Trindade, Florianópolis/SC. Cogitare Enfermagem, 15(4), 603-608. http:// dx.doi.org/10.1590/s0102-79722009000100012

Chang, J., Cluss, P., Burke, J., Hawker, L., Dado, D., Goldstrohm, S., \& Scholle. (2011). Partner violence screening in mental health. General Hospital Psychiatry, 33, 58-65. http://dx.doi. org/10.1016/j.genhosppsych.2010.11.009

Colossi, P. M., \& Falcke, D. (2013). Gritos do silêncio: A violência psicológica no casal. Psico,
44(3), 310-318. Retrieved from https://dialnet. unirioja.es/descarga/articulo/5631422.pdf

Colossi, P. M., Marasca, A. R., \& Falcke, D. (2015). De geração em geração: A violência conjugal e as experiências na família de origem. Psico, 46(4), 493-502. http://dx.doi.org/10.15448/19808623.2015.4.20979

Colossi, P. M., Razera, J., Haack, K. R., \& Falcke, D. (2015). Violência conjugal: Prevalência e fatores associados. Contextos Clínicos, 8(1), 5566. doi: $10.4013 /$ ctc. 2015.81 .06

Conroy, A. A. (2014). Marital infidelity and intimate partner violence in rural Malawi: A dyadic investigation. Archives of Sexual Behavior, 43(7), 1303-1314. doi: 10.1007/s10508-0140306-2

D’Oliveira, A. F. P. L., Schraiber, L. B., França, I., Júnior, Ludermir, A. B., Portella, A. P., Diniz, C. S., Couto, M. T., \& Valença, O. (2009). Fatores associados à violência por parceiro íntimo em mulheres brasileiras. Revista de Saúde Pública, 43(2), 299-310. Retrieved from http://www. scielo.br/pdf/rsp/v43n2/7172.pdf

Dourado, S. M., \& Noronha, C. V. (2015). Marcas visíveis e invisíveis: Danos ao rosto feminino em episódios de violência conjugal. Ciência \& Saúde Coletiva, 20(9), 2911-2920. https:// dx.doi.org/10.1590/S0103-73312014000200016

Drigotas, S. M., Safstrom, C. A., \& Gentilia, T. (1999). An investment model prediction of dating infidelity. Journal of Personality \& Social Psychology, 77, 509-524.

Falcke, D., \& Wagner, A. (2005). A dinâmica familiar e o fenômeno da transgeracionalidade: Definição de conceitos. In A. Wagner (Ed.), Como se perpetua a família? A transmissão dos modelos familiares. Porto Alegre, RS: Editora da Pontifícia Universidade Católica do Rio Grande do Sul.

Falcke, D., \& Wagner, A. (2011). A violência na conjugalidade: Possibilidades de intervenção. In T. Féres-Carneiro (Ed.), Casal e Família: Conjugalidade, parentalidade e psicoterapia (pp. 149-1157). São Paulo, SP: Casa do Psicólogo.

Fang, X., \& Corso, P. S. (2007). Child maltreatment, youth violence, and intimate partner violence. American Journal of Preventive Medicine, 33(4), 281-290. 
Fergusson, C. J. (2011). Love is a battlefield: Risk factors and gender disparities for domestic violence among Mexican Americans. Journal of Aggression, Maltreatment \& Trauma, 20(2), 227-236. doi: 10.1016/j.chiabu.2005.10.006

Flynn, A., \& Graham, K. (2010). "Why did happen? A review and conceptual framework for research on perpetrors' and victims' explanations for intimate partner violence Aggression and Violent Behavior, 15, 239-251. doi: 10.1016/j. avb.2010.01.002

Follingstad, D. R., \& Edmundson, M. (2010). Is psychological abuse reciprocal in intimate relationships? Data from a national sample of American adults. Journal of Family Violence, 25(5), 495-508. doi: 10.1007/ s10896010-9311-y

Giordano, P. C., Manning, W. D., Longmore, M. A., \& Flanigan, C. M. (2012). Developmental shifts in the character of romantic and sexual relationships from adolescence to young adulthood. In A. Booth, S. L. Brown, N. S. Landale, W. D. Manning, \& S. M. McHale (Eds.), Early adulthood in a family context (pp. 133-164). New York: Springer.

Godbout, N., Lussier, Y., \& Sabourin, S. (2006). Early abuse experiences and subsequent gender differences in couple adjustment violence and victims. Violence and Victimcs, 21(6), 744-760. https://doi.org/10.1891/0886-6708.21.6.744

Gover, A. R., Park, M., Tomsich, E. A., \& Jennings, W. G. (2011). Dating violence perpetration and victimization among South Korean college students: A focus on gender and childhood maltreatment. Journal of Interpersonal Violence, 26(6), 1232-1263. doi: $10.1177 / 0886260510368161$

Hetzel-Riggin, M. D., \& Meads, C. L. (2011). Childhood violence and adult partner maltreatment: The roles of coping style and psychological distress. Journal of Family Violence, 26, 585593. doi: 10.1007/s10896-011-9395-z

Hirigoyen, M. F. (2006). A violência no casal: Da coação psicológica à agressão física. Rio de Janeiro, RJ: Bertrand Brasil.

Kerley, K. R., Xu, X. H., Sirisunyaluck, B., \& Alley, J. M. (2010). Exposure to family violence in childhood and intimate partner perpetration or victimization in adulthood: Exploring intergenerational transmission in urban Thailand.
Journal of Family Violence, 25(3), 337-347. doi: 10.1007/s10896-009-9295-7

Kim, H. K, Laurent, H. K, Capaldi, D. M, \& Feingold, A. (2008). Men's aggression toward women: A 10-year panel study. Journal of Marriage and the Family, 70(5), 1169-1187. doi: 10.1111/j.17413737.2008.00558.x

Kline, G. H., Pleasant, N. D., Whitton, S. W., \& Markman, H. J. (2006). Understanding couple conflict. In A. L. Vangelisti \& D. Perlman (Eds.), The Cambridge handbook of personal relationships (pp. 445-462.). Cambridge, UK: Cambridge University Press.

Kronbauer, J. F. D., \& Meneghel, S. N. (2005). Perfil da violência de gênero perpetrada por companheiro. Revista de Saúde Pública, 39(5), 695-701.

Lamoglia, C. V. A., \& Minayo, M. C. S. (2009). Violência conjugal, um problema social e de saúde pública: Estudo em uma delegacia do interior do Rio de Janeiro. Ciência \& Saúde Coletiva, 14, 595-604. http://dx.doi.org/10.1590/ S1413-81232009000200028

Law no. 11.340. (2006). Lei Maria da Penha. Retrieved from https:/www.cairu.br/biblioteca/ arquivos/Direito/lei_maria_penha.pdf

Le Blanc-Louvry, I., Thureau, S., Gricourt, C., \& Proust, B. (2015). Conjugal violence: A comparison of violence against men by women and women by men. Journal of Forensic and Legal Medicine, 31, 42-46. http://dx.doi. org/10.1016/j.jflm.2014.12.014

Marasca, A. R., Colossi, P. M., \& Falcke, D. (2013). Violência conjugal e família de origem: Uma revisão sistemática da literatura de 2006 a 2011. Temas em Psicologia, 21(1), 221-243. doi: 10.9788/TP2013.1-16

Martín-Baena, D., Montero-Piñar I., Escribà-Agüir, V., \& Vives-Cases, C. (2015). Violence against young women attending primary care services in Spain: Prevalence and health consequences. Family Practice, 32(4), 381-386. doi: 10.1093/ fampra/cmv017

Martínez, V. T. P., \& Marín, Y. H. (2009). La violencia psicológica de género, una forma encubierta de agresión. Revista Cubana de Medicina General Integral, 25(2). Retrieved from http://scielo.sld. cu/pdf/mgi/v25n2/mgi10209.pdf 
Martins, A. F. R. S. (2012). Comportamentos extradiádicos offline e online nas relações de namoro: Diferenças de género nos motivos, prevalência e correlatos (Master's thesis, Universidade de Coimbra, Faculdade de Psicologia e de Ciências da Educação, Coimbra, Portugal).

Martins, A., Pereira, M., \& Canavarro, M. C. (2014). Comportamentos extra-diádicos nas relações de namoro: Diferenças de sexo na prevalência e correlatos. Análise Psicológica, 32(1), 45-62. doi: 10.14417/ap.740

Melchert, T. (1998). A review of instruments for assenssing family history. Clinical Psychology Review, 18(2), 163-187.

Milner, J. S., Thomsen, C. J., Crouch, J. L., Rabenhorst, M. M., Martens, P. M., Dyslin, C. W. \& Merrill, L. L. (2010). Do trauma symptoms mediate the relationship between childhood physical abuse and adult child abuse risk? Child Abuse and Neglect, 34(5), 332-344. http://dx.doi.org/10.1016/j.chiabu.2009.09.017

Moraes, C. L., Hasselmann, M. H., \& Reichenheim, M. E. (2002). Adaptação transcultural para o português do instrumento "Revised Conflict Tactics Scales (CTS2)", utilizado para identificar a violência entre casais. Cadernos de Saúde Pública, 18, 163-176.

Oliveira, R. N. G, Gessner, R., Brancaglioni, B. C. A, Fonseca, R. M. G. S., \& Egry, E. Y. (2016). A prevenção da violência por parceiro(a) íntimo(a) na adolescência: Uma revisão integrativa. Revista da Escola de Enfermagem da USP, 50(1), 137-147. http://dx.doi.org/10.1590/ S0080-623420160000100018

Ortiz, J. M. C., Leiva, P. G., \& Jacinto, L. G. (2009). Celos y emociones: factores de la relación de pareja en la reacción ante la infidelidade. Athenea Digital, 15, 39-55.

Paixão, G. P. N., Gomes, N. P., Diniz, N. M. F., Couto, T. M., Vianna, L. A. C., \& Santos, S. M. P. (2014). Situações que precipitam conflitos na relação conjugal: O discurso de mulheres. Texto Contexto Enfermagem, 23(4), 1041-1049. https:// dx.doi.org/10.1590/0104-07072014003290013

Panuzio, J., \& DiLillo, D. (2010). physical, psychological, and sexual intimate partner aggression among newlywed couples: Longitudinal prediction of marital satisfaction. Journal of Family Violence, 25(7), 689-699. doi: 10.1007/s10896-010-9328-2
Paradis, A. D., Reinherz, H. Z., Giaconia, R. M., Beardslee, W. R., Ward, K., \& Fitzmaurice, G. M. (2009). Long-term impact of family arguments and physical violence on adult functioning at age 30 years: Findings from the simmons longitudinal study. Journal of American Academic Child and Adolescence Psychiatry, 48(3), 290-298.

Pedro, M. M. F. (2013). Relação conjugal e relação pais-filhos: Estudo de variáveis mediadoras $e$ moderadoras (Doctoral dissertation, Universidade de Lisboa, Faculdade de Psicologia, Lisboa, Portugal).

Peixoto, M. M., \& Heilborn, M. L. (2016). Mulheres que amam demais: Conjugalidades e narrativas de experiência de sofrimento. Estudos Feministas, 24(1), 406. Retrieved from http:// www.scielo.br/pdf/ref/v24n1/1805-9584ref-24-01-00045.pdf

Prado, L. C. (2012). As múltiplas faces da infidelidade conjugal. Novo Hamburgo, RS: Sinopsys.

Quissini, C., \& Coelho, L. R. M. (2014). A influência das famílias de origem. Pensando Famílias, 18(2), 34-47

Rodrigues, D. P., Gomes-Sponholz, F. A., Stefanelo, J., Nakano, A. M. S., \& Monteiro, J. C. S. (2014). Intimate partner violence against pregnant women: Study about the repercussions on the obstetric and neonatal results. Revista da Escola de Enfermagem. 48(2), 206-213. doi: 10.1590/ S0080-623420140000200002

Rosa, A. G., Boing, A. F., Büchele, F., Oliveira, W. F., \& Coelho, E. B. S. (2008). A violência conjugal contra a mulher a partir da ótica do homem autor da violência. Saúde Sociedade, 17(3), 152-160.

Santos, A. R., Marin, A. H., \& Castoldi, L. (2013). Percepção de mães e adolescentes sobre a violência intrafamiliar por meio da construção do genograma. Contextos Clínicos, 6(2), 174184. doi: $10.4013 /$ ctc. 2013.62 .10

Schraiber, L. B., D’Oliveira A. F. P. L., \& França, I., Júnior. (2008). Violência sexual por parceiro íntimo entre homens e mulheres no Brasil urbano. Revista de Saúde Pública, 42(1), 127-137. http:// dx.doi.org/10.1590/S0034-89102008000800015

Shuler, C. (2010). Male victims of intimate partner violence in the United States: An examination of the review of literature through the critical theoretical perspective. International Journal of Criminal Justice Sciences, 5(1), 163-173. 
Retrieved from http://www.sascv.org/ijcjs/pdfs/ carolettaijcjs2010vol5iss1.pdf

Straus, M. A., Hamby, S. L., Boncy-McCoy, S., \& Sugarman, D. B. (1996). The Revised Conflict Tactics Scales (CTS2): Development and preliminary psychometric data. Journal of Family Issues, 17(3), 283-316. http://dx.doi. org/10.1177/019251396017003001

Tichy, L. L., Becker, J. V., \& Sisco, M. M. (2009). The downside of patriarchal benevolence: Ambivalence in addressing domestic violence and socio-economic considerations for women of Tamil Nadu, India. Journal of Family Violence, 24(8), 547-558. doi: 10.1007/s10896009-9253-4

Trindade, R. F. C., Almeida, A. M., \& Rozendo, C. A. (2008). Infidelidade masculina e violência doméstica: Vivência de um grupo de mulheres. Ciencia y Enfermería, 14(2), 39-46. Retrieved from http://www.scielo.cl/pdf/cienf/ v14n2/art06.pdf

Vatnar, S. K. B., \& Bjorkly, S. (2009). Interactional aspects of intimate partner violence result in different help-seeking behaviors in a representative sample of women. Journal of Family Violence, 24(4), 231-241. doi: 10.1007/ s10896-009-9224-9

Vieira, E. M., Perdona, G. S. C., \& Santos, M. A. (2011). Fatores associados à violência física por parceiro íntimo em usuárias de serviços de saúde. Revista de Saúde Pública, 45(4), 730737. Retrieved from http://www.scielo.br/pdf/ rsp/v45n4/2647.pdf

Wagner, A.(Ed.). (2014). Como se perpetua a família: A transmissão de modelos familiares. Porto Alegre, RS: Editora da Pontifícia Universidade Católica do Rio Grande do Sul.
Wilson, K., Mattingly, B. A., Clark, E. M, Weidler, D. J., \& Bequette, A. W. (2011). The Gray Area: Exploring attitudes toward infidelity and the development of the perceptions of dating infidelity scale. The Journal of Social Psychology, 151(1), 63-86.

Whatley, M. A. (2008). Attitudes toward infidelity scale. In D. Knox \& C. Schacht (Eds.), Choices in relationships (9th ed.). Belmont, CA: Thompson Wadsworth.

Whisman, M. A., \& Baucom, D. H. (2012). Intimate relationships and psychopathology. Child Family Psychology, 15, 4-13.

Whiting, J. B., Simmons, L. A., Havens, J. R., Smith, D. B., \& Oka, M. (2009). Intergenerational transmission of violence: The influence of self-appraisals, mental disorders and substance abuse. Journal of Family Violence, 24(8), 639648.

World Health Organization. (2016). Violence against women: Intimate partner and sexual violence against women. Retrieved from http://www. who.int/mediacentre/factsheets/fs239/en/

Yoshihma, M., \& Horrocks, J. (2010). Risk of intimate partner violence: Role of childhood sexual abuse and sexual initiation in women in Japan. Children and Youth Services Review, 32(1), 28-37. doi: 10.1016/j.childyouth.2009.06.013
Received: 12/01/2017

$1^{\text {st }}$ revision: $05 / 05 / 2017$

$2^{\text {nd }}$ revision: $04 / 01 / 2018$

Accepted: 05/06/2018

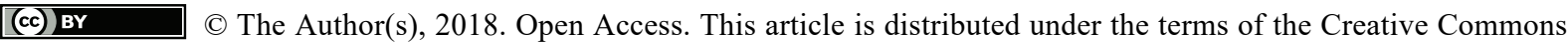
Attribution 4.0 International License (http://creativecommons.org/licenses/by/4.0/), which permits unrestricted use, distribution, and reproduction in any medium, provided you give appropriate credit to the original author(s) and the source, provide a link to the Creative Commons license, and indicate if changes were made. 